\title{
Diversity and distribution of ferns in forest over limestone in Cebu Island Key Biodiversity Areas (KBAs), Philippines
}

\author{
EDGARDO P. LILLO ${ }^{1,2, v}$, ARCHIEBALD B. MALAKI ${ }^{1,3, v v}$, STEVE MICHAEL T. ALCAZAR ${ }^{1,3}$, \\ RAAMAH ROSALES ${ }^{1, v \vee v}$, BERNARDO R. REDOBLADO ${ }^{1}$, ERWIN PANTINOPLE ${ }^{1}$, RITCHE U. NUEVO ${ }^{1}$, \\ ROBERTO C. CUTILLAR ${ }^{1}$, ARNALDO ALMIRANTE ${ }^{1}$, INOCENCIO E. BUOT JR ${ }^{4, v v v v}$

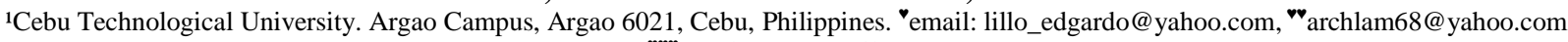 \\ vwepoch7era@gmail.com \\ ${ }^{2}$ Department of Forest Biological Sciences, College of Forestry and Natural Resources, University of the Philippines Los Baños, College Laguna 4031, \\ Laguna, Philippines \\ ${ }^{3}$ School of Environmental Science and Management, University of the Philippines Los Baños, College Laguna 4031, Laguna, Philippines \\ ${ }^{4}$ Institute of Biological Sciences, University of the Philippines Los Baños College Laguna (4031), Laguna, Philippines. Tel: +63-922-8140447 ${ }^{\text {}}$ ( \\ iebuot@up.edu.ph
}

Manuscript received: 25 September 2019. Revision accepted: 31 December 2019.

\begin{abstract}
Lillo EP, Malaki AB, Alcazar SMT, Rosales R, Redoblado BR, Pantinople E, Nuevo RU, Cutillar RC, Almirante A, Buot IE Jr. 2020. Diversity and distribution of ferns in forest over limestone in Cebu Island Key Biodiversity Areas (KBAs), Philippines. Biodiversitas 21: 413-421. Three forest areas of Cebu Island, Philippines were recognized as Key Biodiversity Areas (KBAs) by Department of Environment and Natural Resources [DENR], Philippines based on the criteria of vulnerability and irreplaceability, namely Nug-as of Alcoy, Palinpinon Range of Dalaguete, and Mt. Lantoy of Argao. The study aimed to assess the composition, diversity, and distribution of ferns in the aforementioned KBA's. Quadrat at $20 \mathrm{~m}$ x $20 \mathrm{~m}$ was established within the $2000 \mathrm{~m}$ transect line at an interval of $200 \mathrm{~m}$. Result showed a total of 50 species, categorized into 15 families and 29 genera for 30 quadrats. Twelve species were considered as new records on Cebu. Thirteen species were recorded in both Mt. Lantoy and Nug-as forest KBA's, but absent in Palinpinon range. While 6 species were recorded as unique to Nug-as forest. Nug-as forest and Mt. Lantoy showed a relative value of very high species diversity. Nug-as forest and Mt. Lantoy KBA forming into one cluster and Palinpinon range proved to have a distinct fern species composition, and form another cluster. Local government units (LGU) in every KBA need to recognize the necessity of biodiversity information in their localities that would facilitate information sharing and awareness, hence enhancing protection and conservation of unique biodiversity, since they are at the forefront of local action.
\end{abstract}

Keywords: Cebu Island, diversity, ferns, forests over limestone, Mt. Lantoy, Nug-as forest, Palinpinon range

\section{INTRODUCTION}

The Philippines is one of the 25 mega diverse countries but it also one of the 25 hotspots identified for conservation based on the high number of endemic species and extent of habitat loss in the country (Myers et al. 2000). The forest cover of Cebu Island is now less than $1 \%$ of its total land area (Mallari et al. 2001). Several forest species recorded in the late 1950s are now considered locally extinct (Rabor 1959; Brooks et al.1995; Magsalay et al. 1995; Collar et al. 1999)

Identification of KBAs for both terrestrial and marine areas followed the process outlined in Langhammer et al. (2007). The criteria of vulnerability and irreplaceability were both applied. Vulnerability was triggered by the confirmed presence of one or more globally threatened species, classified as Critically Endangered (CR), Endangered (EN), and Vulnerable (VU) based on the IUCN Red List of Threatened Species (http://www.iucnredlist.org). The Nug-as Forest of Alcoy, Cebu, Palinpinon Range of Dalaguete, Cebu, and Mt. Lantoy of Argao, Cebu was among the 117 terrestrial areas recognized as KBA's (KBA 85). The new KBA site has a total area of 10,457 ha. This site has two critically endangered species, two endangered species, four vulnerable species and 16 restricted-range species (Conservation International Philippines, Department of Environment and Natural Resources [DENR]-Protected Areas and Wildlife Bureau, and Haribon Foundation 2006).

Vascular epiphytes, including orchids, bromeliads, aroids, and pteridophytes, are important components of the vegetation in tropical montane forests. Ferns are plants belonging to the division Pteridophyta. They have neither flowers nor seeds and they reproduce by means of a single unit known as spore (Buot 1999). Ferns once dominate terrestrial plant communities over the entire globe (Vogel et al. 1999) and are still present in most terrestrial ecosystems depending on the agroclimatic conditions and degree of human disturbances (Odland et al. 1995). Ferns are good candidates to address important issues related to the assessment, monitoring, and restoration of biodiversity (Alcala et al. 2019; De los Angeles and Buot 2012, 2018).

However, only few attempts have been made to model fern distributions from environmental characteristics (Alcala et al. 2019; Delos Angeles and Buot 2012, 2018), or to investigate broad-scale patterns in fern diversity. Several books have been published regarding Philippine Pteridophytes. Most are on floristics only (Copeland 1958; 
Amoroso 1987; Barcelona 2002; Banaticla and Buot 2008). Foremost was the three-volume work of Copeland (1958), which accounted for 20 families, 155 genera and 950 species.

Botanical assessments such as floristic composition, species diversity and structural analysis are essential for providing information on species richness for forest management purposes, and in understanding forest ecology and ecosystem functions (Giriraj et al. 2008; Pappoe et al. 2010). Baseline data including distribution, and threats to species is vital in identifying plant species at risk, and for appropriate conservation planning (Rivers et al. 2010). The primary aim of the study was to assess the composition, diversity, and distribution of fern species in Nug-as, Palinpinon Range and Mt. Lantoy KBAs for conservation and protection purposes

\section{MATERIALS AND METHODS}

\section{Study area}

The study was conducted in the Key Biodiversity Area (KBA's) of the Southern part of Cebu Island Philippines. The site includes: Mt. Lantoy of the Municipality of Argao $\left(09^{\circ} 549 \mathrm{~N}, 123^{\circ} 329 \mathrm{E}\right)$ with an elevation ranges from 100 $700 \mathrm{~m}$, Nug-as forest $\left(09^{\circ} 71^{\prime} \mathrm{N}, 123^{\circ} 44^{\prime} \mathrm{E}\right)$ ranges from $500-960 \mathrm{~m}$ of the Municipality of Alcoy, and Palinpinon Range $\left(09^{\circ} 82 \mathrm{~N}, 123^{\circ} 49 \mathrm{E}\right)$ of the Municipality of Dalaguete, Cebu with an elevation ranges from 500-600 m (Figure 1).

\section{Establishment of sampling plots and plant species identification}

Ten $20 \mathrm{~m}$ x $20 \mathrm{~m}$ quadrats were established within the transect line at an interval of $200 \mathrm{~m}$. The establishment of transect line largely depended on the accessibility of the forest for at least a minimum of $1000 \mathrm{~m}$ and a maximum of $2,000 \mathrm{~m}$ in length. All of the fern species within the plot were identified. Total number of species and individuals within the plot were tallied and documented. Identification of sample specimens was done through use of floras and manuals (Copeland 1958; Fernando 2007), herbarium vouchers (Philippine National Museum file), digital database (Co's Digital Flora of the Philippines; https://www.philippineplants.org), and online literature (http://www.theplantlist.org).
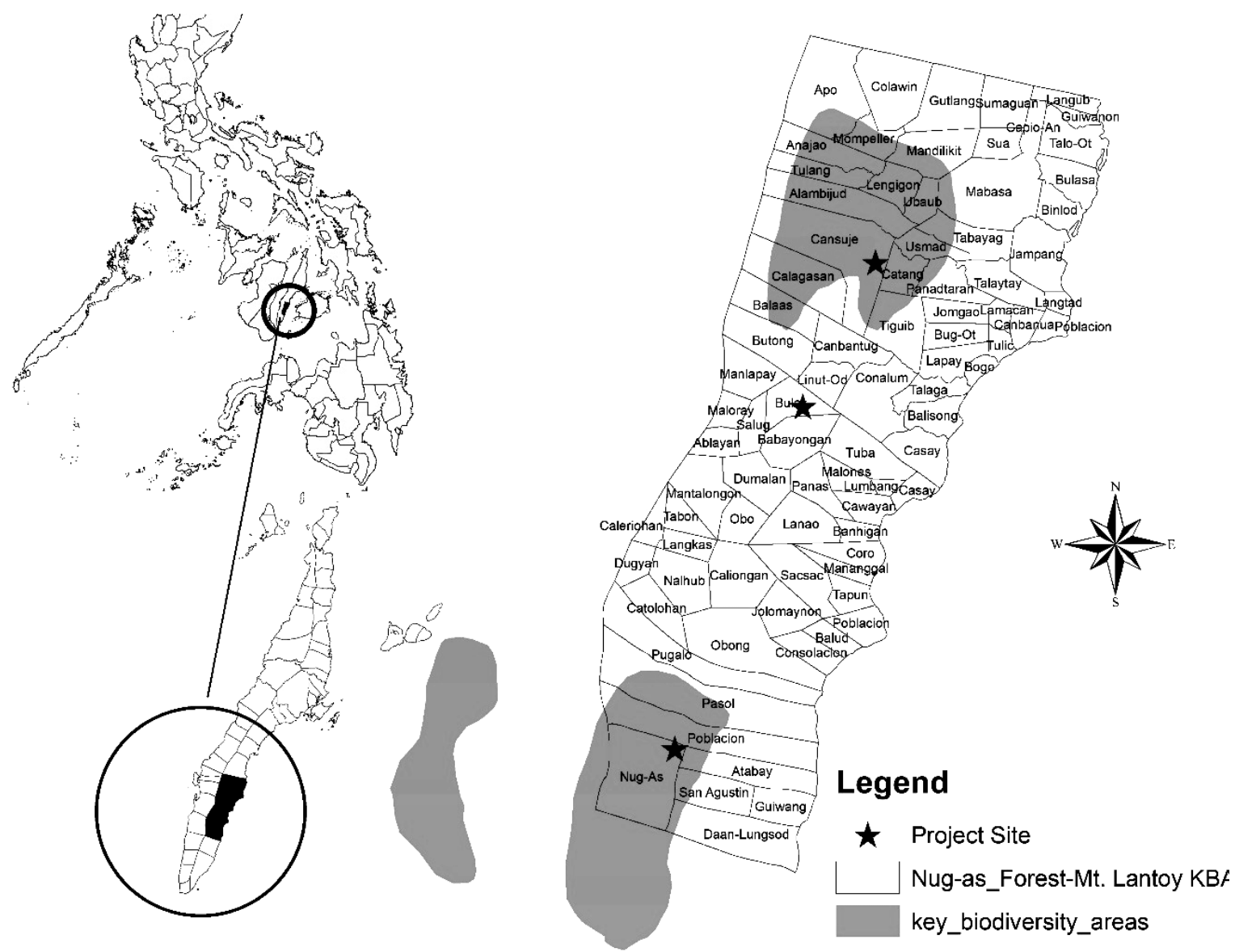

Figure 1. The Philippine map showing Cebu Island, and the study sites and plot locations (GIS generated map; Landsat 8; www.earthexplorer.usgs.ph; NAMRIA; Philippine GIS data) 


\section{Conservation status of species}

Conservation status of the species was determined based on classifications by the Department of Environment and Natural Resources (DENR 2017) and the International Union for the Conservation of Nature (IUCN 2017). The identified herbarium specimens were deposited in the newly established mini-museum of the Cebu Technological University-Argao Campus. The mini-museum showcased the species collected from different KBA's for instruction, research, and public service purposes.

\section{Data analysis}

Diversity of plant species

Fern species diversity was computed and interpreted by using $\mathrm{H}^{\prime}$ through the Multivariant Statistical Package (MVSP) software. Shannon diversity index was sensitive to areas with fragmented forests like Mt. Lantoy, Palinpinon range, and Nug-as forest.

Compilation of $\mathrm{H}^{\prime}$ values of all sample plots provided valuable information, particularly in explaining relationship with diversity and the presence/absence (PRAB) of anthropogenic or natural stress factors in the site.

\section{Cluster and ordination analyses}

The cluster analysis of fern species was done using XLSTAT Version 2016.02.28451 in Microsoft Excel. The general analytical methods performed in the study was modified from Andersen et al. (2009) and Legendre et al. (2008). Differences in fern species composition between sites were assessed with floristic dissimilarity matrices; 1. Presence/absence (PRAB) and 2. Species abundance (ABU) data. Cluster analysis of fern community and composition were designed using Jaccard dissimilarity matrix and Sorensen dissimilarity matrix using Multivariate Statistical Package (MVSP) software.

\section{RESULTS AND DISCUSSION}

\section{Characteristics of the Key Biodiversity Areas in southern Cebu}

Mt. Lantoy KBA, in general, is characterized as forest over limestone habitat types with an elevation ranges from 100-800 m, dominated by Carcar formation (Lillo et al. 2019). Mt. Lantoy has a geological composition of mostly raised sedimentary and metamorphic rocks-a considerable part of it being limestone (Audley-Charles et al. 1979). The habitat type is comparable to the forest over limestone of the Philippine forest formation of Fernando et al. (2008), and similar to the so-called 'Molave' (Vitex parviflora) forest as described by Whitford (1911). The forest is dominated by less dense vegetation, small size trees, and few large trees. The larger trees prohibit the penetration of solar radiation into the forest floor, this can be observed in the upper elevation. Lesser vegetation and smaller size trees were observed in the lower part of the mountain. The forest is also covered by large size of outcrop bedrocks with shallow soil and undecomposed organic matters (Lillo et al. 2019).
Palinpinon range, in general, is also characterized as forest over limestone's habitat types similar to Mt. Lantoy, with an elevation ranges from 500-600 $\mathrm{m}$, and characterized as having a mountainous topography. Palinpinon range serves also as corridor for the biodiversity species of both Mt. Lantoy and Nug-as forest since it is located in between. The site is covered by smaller size trees ranging from $11-30 \mathrm{~cm}$. The forest is covered by vegetation to almost $40 \%$, canopy cover of $30 \%$, and understory of $50 \%$. The forest is also covered by native trees with almost uniform in height and non-stratified layering as compare to Mt. Lantoy. The high number of small size trees in the study area signified more penetration of solar energy on the forest floor.

Nug-as Forest of the Municipality of Alcoy is characterized as forest over limestone and tropical lowland evergreen forest. The forest over limestone is located in the forest edge and mountain ridge as indicated by larger rock outcrops, while the tropical lowland forest covers majority of the area. Nug-as forest has a total land area of 1,600ha. The 800 ha is covered by plantation and shrub vegetation, with an elevation ranges from 0-960m (Paguntalan 2008). The forest can be compared to Mt. Lantoy, characterized as secondary forest covered by trees with diameter ranges from $15-80 \mathrm{~cm}$, larger and taller among KBA's. The forest was densely cover by $70 \%$ vegetation and a canopy cover of $60 \%$. According to Jakosalem et al. (2012), the forest was covered by various indigenous tree taxa such as Ficus, Syzygium, and Buchanania, and are surrounded by open farmland and intercalating areas of plantation of Swietenia, Tectona, Gmelina, and Eucalyptus species.

\section{Species composition}

A total of 50 species were recorded in the study sites from 30 quadrants (Table 1). The species were categorized into 15 families and 29 genera. The recorded species were just $56 \%$ to the fern species recorded on Mount Banahaw with 83 species, representing 47 genera and 24 families (Banaticla and Buot Jr 2005). Out of 50 species, 12 indigenous species were considered as new records on Cebu Island. Buot (1999) conducted a survey of fern species in Cebu Island, but none of these species were recorded. These species with new record arrived on Cebu Island through natural means (Table 2).

The most represented families are Thelypteridaceae, Pteridaceae, Aspleniaceae, and Polypodiaceae. The same dominant families were recorded on Mount Banahaw (Banaticla and Buot $\mathrm{Jr}$ 2005). Asplenium, Pterida, Lygodium, Adiantum, and Cyclosorus are the most dominant genera (Table 1).

Eighty-six (86) percent of the species were terrestrial, and $7 \%$ were classified as epipetric and epiphytic. Twelve species were identified as having medicinal values (Table 1), 7 species were identified as having food values, and 3 species were potential fiber sources. 
Table 1. Fern species composition in Key Biodiversity Areas (KBA) of Cebu Island, Philippines, showing habitat, uses and conservation status.

\begin{tabular}{|c|c|c|c|c|c|c|}
\hline \multirow[b]{2}{*}{ Family } & \multicolumn{2}{|l|}{ Species } & \multirow[b]{2}{*}{ Habit } & \multirow[b]{2}{*}{ Uses } & \multicolumn{2}{|c|}{ Conservation status } \\
\hline & Scientific name & $\begin{array}{c}\text { Common } \\
\text { name }\end{array}$ & & & $\begin{array}{l}\text { DENR DAO- } \\
2017-11\end{array}$ & $\begin{array}{l}\text { IUCN } \\
2017-3 \\
\end{array}$ \\
\hline Aspleniaceae & Asplenium cuneatum Lam. & - & Epiphytic & $\begin{array}{l}\text { (rhizome) Medicines: vermifuges } \\
\text { (anthelmintic) (Burkill 1985) }\end{array}$ & Not yet assessed & $\mathrm{LC}$ \\
\hline Aspleniaceae & Asplenium unilaterale Lam. & - & Terrestrial & Ornamental (Blanca León 1999) & Not yet assessed & $\mathrm{LC}$ \\
\hline Aspleniaceae & Asplenium lobulatum Mett. & - & Terrestrial & Unidentified uses & Not yet assessed & $\mathrm{LC}$ \\
\hline Aspleniaceae & Asplenium nidus $\mathrm{L}$. & $\begin{array}{l}\text { Pak-pak lawin } \\
1\end{array}$ & Epiphytic or terrestrial & $\begin{array}{l}\text { Food, medicinal, ornamental (Tindall } \\
\text { 1983) }\end{array}$ & VU & $\mathrm{LC}$ \\
\hline Dennstaedtiaceae & $\begin{array}{l}\text { Pteridium aquilinum (L.) Kuhn subsp. } \\
\text { wightianum (J. Agardh) W.C. Shieh }\end{array}$ & Bracken & Terrestrial & $\begin{array}{l}\text { Anti-insect chemicals, such as ecdysones } \\
\text { and Biofuel (Callaghan et al. 1981) }\end{array}$ & Not yet assessed & $\mathrm{LC}$ \\
\hline Dryopteridaceae & Bolbitis heteroclita (C. Presl) Ching & - & Terrestrial & Unidentified uses & Not yet assessed & $\mathrm{LC}$ \\
\hline Gleicheniaceae & Dicranopteris linearis (Burm. f.) Underw. & Kilob & Terrestrial & $\begin{array}{l}\text { Pens, Medicine, woven for mattings, fish- } \\
\text { traps, chair seats, walls, pouches, caps, and } \\
\text { ropes (Tan 2011) }\end{array}$ & Not yet assessed & $\mathrm{LC}$ \\
\hline Lindsaeaceae & Lindsaea adiantoides J.Sm. & - & Terrestrial & Unidentified uses & Not yet assessed & $\mathrm{LC}$ \\
\hline Lygodiaceae & Lygodium auriculatum (Willd.) Alston & & $\begin{array}{l}\text { Terrestrial, usually in } \\
\text { thickets and disturbed } \\
\text { forests }\end{array}$ & $\begin{array}{l}\text { Climbing rachises used for weaving, } \\
\text { making hats, and magic (contra-poison) } \\
\text { bracelets (Brown 1920). }\end{array}$ & Not yet assessed & $\mathrm{LC}$ \\
\hline Lygodiaceae & Lygodium circinatum (Burm. f.) Sw. & Nito puti & $\begin{array}{l}\text { Terrestrial, common in } \\
\text { brush and open sites and } \\
\text { disturbed lowland } \\
\text { forests. }\end{array}$ & $\begin{array}{l}\text { Food and medicine. Weaving (Huxley } \\
\text { 1992). }\end{array}$ & Not yet assessed & $\mathrm{LC}$ \\
\hline Lygodiaceae & Lygodium flexuosum (L.) Sw. & Nito & $\begin{array}{l}\text { Terrestrial, in brush and } \\
\text { open forests at low } \\
\text { altitudes. }\end{array}$ & $\begin{array}{l}\text { Medicinal (hepato-fibrosis, cough, } \\
\text { rheumatism, sprains, scabies, eczema, } \\
\text { jaundice wounds and skin diseases, anti- } \\
\text { inflammatory) (Kirtikar and Basu 1999) }\end{array}$ & Not yet assessed & $\mathrm{LC}$ \\
\hline Lygodiaceae & Lygodium japonicum (Thunb.) Sw. & Nito pula & $\begin{array}{l}\text { Terrestrial in open } \\
\text { forests and thoroughly } \\
\text { cleared sites at low to } \\
\text { medium altitudes. }\end{array}$ & $\begin{array}{l}\text { The plant is used as an expectorant } \\
\text { and diuretic }\end{array}$ & Not yet assessed & $\mathrm{LC}$ \\
\hline Marattiaceae & Christensenia aesculifolia (Blume) Maxon & - & Terrestrial & Unidentified uses & Not yet assessed & $\mathrm{LC}$ \\
\hline Marsileaceae & Marsilea crenata C. Presl & $\begin{array}{l}\text { Dwarf four leaf } \\
\text { clover }\end{array}$ & & $\begin{array}{l}\text { Ornamental plants for outdoor water } \\
\text { gardens (IUCN 2011) }\end{array}$ & Not yet assessed & $\mathrm{LC}$ \\
\hline Nephrolepidaceae & Nephrolepis cordifolia (L.) C. Presl & $\begin{array}{l}\text { Sword Fern } \\
\text { (bayabang) }\end{array}$ & $\begin{array}{l}\text { Terrestrial (epiphytic } \\
\text { and epilithic) }\end{array}$ & $\begin{array}{l}\text { Whole plant is used to cure renal, liver and } \\
\text { skin disorders (Dhiman 1998). } \\
\text { Ornamental fern and often the tubers are } \\
\text { eaten to quench thirst (Chhetri 2006) }\end{array}$ & Not yet assessed & LC \\
\hline Nephrolepidaceae & Nephrolepis exaltata $(\mathrm{L})$ Schott & - & Terrestrial & ornamental (Roux. 2003) & Not yet assessed & $\mathrm{LC}$ \\
\hline Nephrolepidaceae & Nephrolepis falcata (Cav.) C. Chr. & - & Terrestrial & Ornamental plants (Bharrati et al. 2013) & Not yet assessed & $\mathrm{LC}$ \\
\hline
\end{tabular}


Polypodiaceae

Aglaomorpha meyeniana Schott

Polypodiaceae Polypodiaceae

Polypodiaceae

Polypodiaceae

Polypodiaceae

Polypodiaceae

Polypodiaceae

Pteridaceae

Pteridaceae

Pteridaceae

Pteridaceae

Pteridaceae

Pteridaceae

Pteridaceae

Pteridaceae

Selaginellaceae

Selaginellaceae

Tectariaceae

Tectariaceae

Thelypteridaceae

Thelypteridaceae

Thelypteridaceae

Thelypteridaceae

Thelypteridaceae

Thelypteridaceae

Thelypteridaceae

Thelypteridaceae

Thelypteridaceae

Thelypteridaceae

Thelypteridaceae

Thelypteridaceae
Aglaomorpha splendens Copel.

Leptochilus cantoniensis (Baker) Ching

$=$ Christopteris sagito

Drynaria descensa Copel.

Goniophlebium pseudoconnatum Copel Microsorum heterocarpum (Blume) Ching

Phymatosorus scolopendria (Burm. f.) Pic.

Serm.

Adiantum caudatum $\mathrm{L}$.

Adiantum malesianum J Ghatak

Adiantum lunulatum Burm. f.

Adiantum tenerum $\mathrm{Sw}$.

Doryopteris ludens (Wall. ex Hook.) J. Sm.

Pteris biaurita $\mathrm{L}$.

Pteris pacifica Hieron.

Pteris vittata $\mathrm{L}$

Selaginella engleri Hieron

Selaginella myosurus Alston

Tectaria angulata (Willd.) Copel.

ectaria hilocarpa (Fée) M.G. Price

Ampelopteris prolifera (Retz.) Copel.

Cyclosorus aridus (D. Don) Tagawa

Cyclosorus ciliates (Wall. Ex Benth.) Panigrahi

Cyclosorus crinipes (Hook.) Ching

yclosorus falcilobus Panigrah

Cyclosorus heterocarpus (Blume) Ching

Macrothelypteris polypodioides (Hook.) Holttum

Metathelypteris gracilescens (Blume) Ching

Parathelypteris beddomei (Baker) Ching

Thelypteris grammitoides (Christ) Ching

Pseudophegopteris aurita (Hook.) Ching

Sphaerostephanos diversilobus Holttum
Drynaria quercifolia (L.) J. Sm.
Interrupted

fern

Terrestrial

Epiphytic, epilithic or

terrestrial

Terrestrial

Terrestrial

Terrestrial/epiphytic

Epiphyte or lithophyte

in seasonal areas, in

open forests at low

altitude

terrestrial

Epiphytic

Epiphytic or lithophytic

in exposed sites and

disturbed forests.

Alambrillong Terrestrial Medicinal

Terrestrial

gubat

Kaikai

Terrestrial

Terrestrial

Terrestrial

Terrestrial

Terrestrial

Terrestrial or epipetric

Epipetric

Terrestrial

Terrestrial

Terrestrial

Terrestrial

Terrestrial

Terrestrial

Terrestrial

Terrestrial

Terrestrial

Terrestrial

Terrestrial

Terrestrial

Terrestrial

Medicinal

Medicinal blood disorders and venereal diseases,

headache and joint pain (Herrick 1977)

Unidentified uses

Not yet assessed

LC

Unidentified uses

Unidentified uses

Unidentified uses

Medicinal and

ornamental

Unidentified uses

Unidentified uses

Unidentified uses

Unidentified uses

Unidentified uses

Unidentified uses

Unidentified uses

Unidentified uses

Unidentified uses

Unidentified uses

Unidentified uses

Unidentified uses

Unidentified uses

Unidentified uses

Unidentified uses

Unidentified uses

Unidentified uses

Unidentified uses

Unidentified uses

Unidentified uses

Unidentified uses

Unidentified uses

Unidentified uses

Unidentified uses
Not yet assessed

Not yet assessed

Not yet assessed

Not yet assessed

VU

LC
LC

Not yet assessed

Not yet assessed

Not yet assessed

LC

LC

Not yet assessed

LC

Not yet assessed

LC

Not yet assessed

Not yet assessed

Not yet assessed

Not yet assessed

Not yet assessed

Not yet assessed

Not yet assessed

Not yet assessed

Not yet assessed

Not yet assessed

Not yet assessed

Not yet assessed

Not yet assessed

Not yet assessed

Not yet assessed

Not yet assessed

Not yet assessed

Not yet assessed

Not yet assessed

Not yet assessed

Not yet assessed

LC

LC

LC

LC

LC

LC

LC

LC

LC

LC

LC

LC

LC

LC

LC

LC

LC 
Table 2. New record of fern species on Cebu Island (Co's Digital Flora of the Philippines)

\begin{tabular}{|c|c|c|c|c|}
\hline \multirow{2}{*}{ Family } & \multirow{2}{*}{ Species } & \multirow{2}{*}{ Endemicity } & \multicolumn{2}{|c|}{ Conservation status } \\
\hline & & & DENR-DAO 2017-11 & IUCN 2017-3 \\
\hline Aspleniaceae & Asplenium unilaterale Lam. & NEI (Africa) & Not yet assessed & $\mathrm{LC}$ \\
\hline Osmundaceae & Osmunda claytoniana $\mathrm{L}$. & NEI (North America) & Not yet assessed & $\mathrm{LC}$ \\
\hline Pteridaceae & Doryopteris ludens (Wall. ex Hook.) J. Sm. & NEI (Bangladesh) & Not yet assessed & LC \\
\hline Pteridaceae & Pteris pacifica Hieron. & NEI (Australia) & Not yet assessed & $\mathrm{LC}$ \\
\hline Pteridaceae & Adiantum malesianum J. Ghatak & NEI (China) & Not yet assessed & LC \\
\hline Thelypteridaceae & Thelypteris grammitoides (Christ) Ching & NEI (China) & Not yet assessed & $\mathrm{LC}$ \\
\hline Thelypteridaceae & Pseudophegopteris aurita (Hook.) Ching & NEI (Borneo) & Not yet assessed & $\mathrm{LC}$ \\
\hline Thelypteridaceae & Cyclosorus falcilobus Panigrahi & NEI (India) & Not yet assessed & $\mathrm{LC}$ \\
\hline Thelypteridaceae & Cyclosorus heterocarpus (Blume) Ching & NEI (China) & Not yet assessed & $\mathrm{LC}$ \\
\hline Thelypteridaceae & Cyclosorus aridus (D. Don) Tagawa & NEI (China) & Not yet assessed & $\mathrm{LC}$ \\
\hline Thelypteridaceae & Cyclosorus ciliatus Panigrahi & NEI (China) & Not yet assessed & $\mathrm{LC}$ \\
\hline Thelypteridaceae & Cyclosorus crinipes (Hook.) Ching & NEI (China) & Not yet assessed & $\mathrm{LC}$ \\
\hline
\end{tabular}

Note: NEI-Non-Endemic Indigenous species

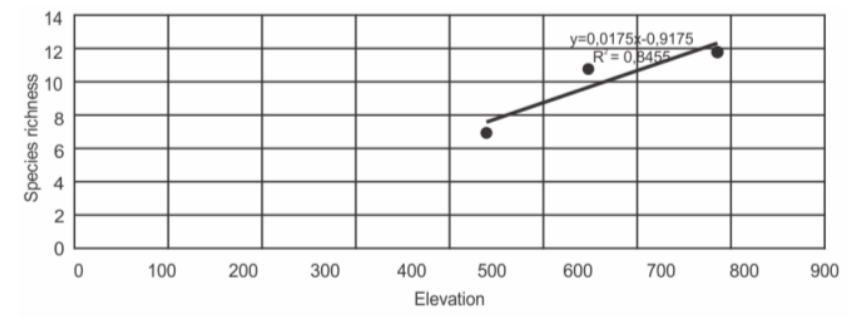

Figure 2. Correlation between species richness and elevation

Out of the 50 species, 3 species were found endemic to the Philippines (Selaginella myosurus Alston, Lindsaea adiantoides J.Sm and Drynaria descensa Copel), one was introduced from South America (Adiantum tenerum Sw.) and 46 species were considered as indigenous species (Table 3). All of the fern species were recorded in Nug-as forest of Alcoy (100\%), 90\% of species were recorded in Mt. Lantoy, and 64\% were recorded in Palinpinon range (Table 3). Of the 50 species, 13 species were recorded in both Mt. Lantoy and Nug-as forest KBA's, but absent in Palinpinon range. While 6 species were recorded only in Nug-as forest (Table 3).

Conservation status of fern species was determined based on IUCN 2017 and DENR-DAO 2017-11 classification. Based on the IUCN classification, Aglaomorpha splendens Copel was found to be threatened and categorized as Vulnerable. The rest of the species were classified as Least Concerned (LC) and are still dominant in the wild (Table 1). However, based on DENR classification 2 species are found to be threatened or categorized as vulnerable. The species are Asplenium nidus L. and Drynaria quercifolia (L.) J. Sm. The rest of the species are still dominant in the wild (Table 1). Asplenium nidus L. was recorded only in Nug-as forest of Alcoy and was absent in Palinpinon range and in Mt. Lantoy. While the Drynaria quercifolia (L.) J. Sm was observed both in Mt. Lantoy and Nug-as forest (Table 1).

Nug-as forest and Mt. Lantoy as KBA serve as habitat to high fern species diversity, threatened, endemic and

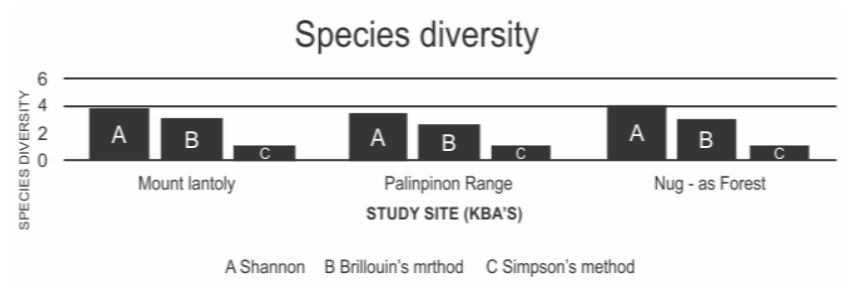

Figure 3. Species diversity per study sites (KBA's).

unique species. Based on site characterization, Nug-as forest and Mt. Lantoy have more varied environmental conditions, with higher elevations, as compared to Palinpinon range. Based on Pearson "R" correlation, there is a strong positive correlation $\left(\mathrm{R}^{2}=0.8455\right)$ between site elevation and with species diversity (Figure 2). In addition, the forest structure and species composition of Nug-as forest and Mt. Lantoy are different as compared to Palinpinon range. Esperanza (1993) reported that the factor affecting the distribution of Pteridophyte species was the floristic composition and structure of woody vegetation along the slope.

\section{Diversity of fern species}

Based on Shannon diversity index (H'), Brillouin's index (HB) and Simpson diversity index (Ds) computed through MVSP software, both Nug-as forest and Mt. Lantoy have higher species diversity as compared with Palinpinon range (Figure 3). The two study sites (Nug-as forest and Mt. Lantoy) have a relative value of very high species diversity (Mac Donald 2003). Species diversity is a community attribute related to stability, productivity, and trophic structure (McIntosh 1967, McNaughton 1977, Tilman 1996). Therefore, an area with high species diversity results in a more stable and productive ecosystem as could be observed in Nug-as forest and Mt. Lantoy KBA's. The result of the study concurred with the findings of Lillo (2019) with regard to the diversity of native trees in Mt. Lantoy $\left(\mathrm{H}^{\prime}=3.5\right)$ (MacDonald 2003). 
Table 3. The distribution of Fern species in KBA of the Cebu Island, Philippines

\begin{tabular}{|c|c|c|c|c|c|}
\hline \multirow{3}{*}{ Family } & \multirow{3}{*}{ Species } & \multicolumn{4}{|c|}{ Distribution } \\
\hline & & & Key I & Biodiversity & Areas \\
\hline & & Endemicity & $\begin{array}{l}\text { Mt. } \\
\text { Lantoy }\end{array}$ & $\begin{array}{l}\text { Palinpinon } \\
\text { Range }\end{array}$ & $\begin{array}{l}\text { Nug-as } \\
\text { Forest }\end{array}$ \\
\hline Aspleniaceae & Asplenium cuneatum Lam. & NEI (Africa) & + & + & + \\
\hline Aspleniaceae & Asplenium unilaterale Lam. & NEI (Africa) & + & + & + \\
\hline Aspleniaceae & Asplenium lobulatum Mett. & NEI (Borneo) & + & + & + \\
\hline Aspleniaceae & Asplenium nidus L. & NEI (Africa) & & & + \\
\hline Dennstaedtiaceae & Pteridium aquilinum (L.) Kuhn & NEI (China) & + & & + \\
\hline Dryopteridaceae & Bolbitis heteroclita (C. Presl) Ching & NEI (Bangladesh) & & & + \\
\hline Gleicheniaceae & Dicranopteris linearis (Burm. f.) Underw. & NEI (Singapore) & + & & + \\
\hline Lindsaeaceae & Lindsaea adiantoides J.Sm. & $\mathrm{PE}$ & + & & + \\
\hline Lygodiaceae & Lygodium auriculatum (Willd.) Alston & NEI (Indochina) & + & & + \\
\hline Lygodiaceae & Lygodium circinatum (Burm. f.) Sw. & NEI (Sri Lanka) & + & + & + \\
\hline Lygodiaceae & Lygodium flexuosum (L.) Sw. & NEI (Sri Lanka) & + & + & + \\
\hline Lygodiaceae & Lygodium japonicum (Thunb.) Sw. & NEI (Sri Lanka) & + & + & + \\
\hline Marattiaceae & Christensenia aesculifolia (Blume) Maxon & NEI (Java) & & & + \\
\hline Marsileaceae & Marsilea crenata $\mathrm{C}$. Presl & NEI (Malaysia) & & & + \\
\hline Nephrolepidaceae & Nephrolepis cordifolia (L.) C. Presl & NEI (Australia) & + & + & + \\
\hline Nephrolepidaceae & Nephrolepis exaltata (L.) Schott & Introduced (South America) & + & + & + \\
\hline Nephrolepidaceae & Nephrolepis falcata (Cav.) C. Chr. & NEI (Philippines) & + & + & + \\
\hline Osmundaceae & Osmunda claytoniana $\mathrm{L}$. & NEI (North America) & & & + \\
\hline Polypodiaceae & Aglaomorpha meyeniana Schott & NEI (Taiwan) & + & + & + \\
\hline Polypodiaceae & Aglaomorpha splendens Copel. & NEI (Sulawesi) & + & + & + \\
\hline Polypodiaceae & Leptochilus cantoniensis (Baker) Ching & NEI (China) & & & + \\
\hline Polypodiaceae & Drynaria descensa Copel. & PE & + & & + \\
\hline Polypodiaceae & Drynaria quercifolia (L.) J. Sm. & NEI (India) & + & & + \\
\hline Polypodiaceae & Goniophlebium pseudoconnatum Copel & NEI (Borneo) & + & + & + \\
\hline Polypodiaceae & Microsorum heterocarpum (Blume) Ching & NEI (Borneo) & + & & + \\
\hline Polypodiaceae & $\begin{array}{l}\text { Phymatosorus scolopendria (Burm. f.) Pic. } \\
\text { Serm. }\end{array}$ & NEI (Africa) & + & & + \\
\hline Pteridaceae & Adiantum caudatum $\mathrm{L}$. & NEI (Bangladesh) & + & & + \\
\hline Pteridaceae & Adiantum malesianum J. Ghatak & NEI (China) & + & & + \\
\hline Pteridaceae & Adiantum lunulatum Burm. f. & NEI (Africa) & + & + & + \\
\hline Pteridaceae & Adiantum tenerum $\mathrm{Sw}$. & Introduced from South America & + & + & + \\
\hline Pteridaceae & Doryopteris ludens (Wall. ex Hook.) J. Sm. & NEI (Bangladesh) & + & + & + \\
\hline Pteridaceae & Pteris biaurita L. & NEI (Andaman Isls) & + & + & + \\
\hline Pteridaceae & Pteris pacifica Hieron. & NEI (Australia) & + & + & + \\
\hline Pteridaceae & Pteris vittata $\mathrm{L}$. & NEI (Africa) & + & + & + \\
\hline Selaginellaceae & Selaginella engleri Hieron & NEI (Borneo) & + & & + \\
\hline Selaginellaceae & Selaginella myosurus Alston & $\mathrm{PE}$ & + & & + \\
\hline Tectariaceae & Tectaria angulata (Willd.) Copel. & NEI (Borneo) & + & & + \\
\hline Tectariaceae & Tectaria hilocarpa (Fée) M.G. Price & NEI (Borneo) & + & & + \\
\hline Thelypteridaceae & Ampelopteris prolifera (Retz.) Copel. & NEI (Old World tropics) & + & + & + \\
\hline Thelypteridaceae & Cyclosorus aridus (D. Don) Tagawa & NEI (China) & + & + & + \\
\hline Thelypteridaceae & Cyclosorus ciliatus Panigrahi & NEI (China) & + & + & + \\
\hline Thelypteridaceae & Cyclosorus crinipes (Hook.) Ching & NEI (China) & + & + & + \\
\hline Thelypteridaceae & Cyclosorus falcilobus Panigrahi & NEI (India) & + & + & + \\
\hline Thelypteridaceae & Cyclosorus heterocarpus (Blume) Ching & NEI (China) & + & + & + \\
\hline Thelypteridaceae & Macrothelypteris polypodioides (Hook.) Holtt. & NEI (Australia) & + & + & + \\
\hline Thelypteridaceae & Metathelypteris gracilescens (Blume) Ching & NEI (Taiwan) & + & + & + \\
\hline Thelypteridaceae & Parathelypteris beddomei (Baker) Ching & NEI (Borneo) & + & + & + \\
\hline Thelypteridaceae & Thelypteris grammitoides (Christ) Ching & NEI (China) & + & + & + \\
\hline Thelypteridaceae & Pseudophegopteris aurita (Hook.) Ching & NEI (Borneo) & + & + & + \\
\hline Thelypteridaceae & Sphaerostephanos diversilobus Holttum & NEI (Sulawesi) & + & + & + \\
\hline Total & & & 45 & 32 & 50 \\
\hline
\end{tabular}


UPGMA

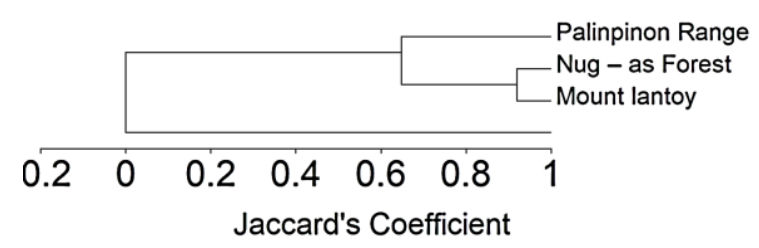

Figure 4. Dendrogram of the three sites per Jaccard similarity coefficient and clustering using the Unweighted Pair Group Method with Arithmetic mean (UPGMA) showing Nug-as Forest and Mt. Lantoy in one cluster.

Cluster analysis of fern species community by both Jaccard and Sorensen dissimilarity matrices through MVSP software, showed that Nug-as forest and Mt. Lantoy KBA were forming one cluster based on species composition, and presence and absence of species (Figure 4 and 5). The fern species in Palinpinon range proved to have a distinct fern species composition different from Nug-as forest and Mt. Lantoy, hence it formed a separate cluster (Figures 4 and 5). The result agreed with the fern species distribution in different study sites (Table 3).

In conclusion, a total of 50 species were recorded in the study sites. The species were categorized into 15 families and 29 genera. Thirteen species were uniquely shared only by Mt. Lantoy and Nug-as forest. However, 6 species were recorded only in Nug-as forest. Twelve native or indigenous species were considered new records on Cebu Island. Nug-as forest and Mt. Lantoy as KBAs showed a relatively high value of Shannon diversity index, forming as one cluster. Palinpinon range, though had been sharing similar species with the former two forests, proved to be different and hence, forming another cluster.

\section{ACKNOWLEDGEMENTS}

The authors would like to acknowledge the Department of Science and Technology (DOST) for considering and approving our research proposal and giving us the budget for three years enough for the implementation of the whole study, and declaring CTU as one of the DOST-Biodiversity Centers through the NICER program in Region 7. The Philippine Council for Agriculture and Aquatic Resources Research Development (PCAARRD) for recommending our proposal to DOST for approval and guide us in the implementation of the study, assisted us in the report preparation, and writing. The CTU System for supporting the research team and allowing the research staff to conduct the study. The CENRO Argao for approving our request to conduct the study in different KBAs.
UPGMA

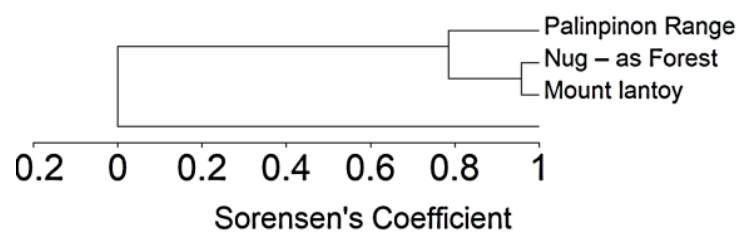

Figure 5. Dendrogram of the three sites per Sorensen similarity coefficient and clustering using the Unweighted Pair Group Method with Arithmetic mean (UPGMA) showingNug-as Forest and Mt. Lantoy in one cluster.

\section{REFERENCES}

Alcala AA, Delos Angeles M and IE Buot Jr. 2019. Fern species diversity across various land-use types of Mt. Makiling, Luzon Island, Philippines. Biodiversitas 20 (9): 2437-2445.

Amoroso, VB. 1987. Medicinal ferns and fern allies of Mindanao. Central Mindanao University, Musuan, Bukidnon, Philippines. https://goo.gl/3gxvSa. [January 16, 2011]

Andersen C, Nielsen TS, Purup S, Kristensen T, Eriksen J, Soegaard K, Sorensen J, Frette XC. 2009. Phyto-estrogens in herbage and milk from cows grazing white clover, red clover, lucerne or chicory-rich pastures. Animal 3 (8): 1189-1195.

Audley-Charles MG, Carter DJ, Barber AJ, Norvick MS, Tjokrosapoetro S. 1979. Reinterpretation of the geology of Seram: Implications for the Banda Arc and northern Australia. J Geol Soc 136: 547-568.

Banaticla MCN, Buot IE Jr. 2005. Altitudinal zonation of pteridophytes on Mt. Banahaw de Lucban, Luzon Island, Philippines. Plant Ecol 180: 135-151. DOI 10.1007/s11258-004-2494-7.

Banaticla MCN, Buot IE Jr.. 2008. Identification, geographic distribution and floristic affinity of pteridophytes on the northeastern slope of Mt. Banahaw de Lucban, Sierra Madre mountain range, Quezon (Luzon Island), Philippines. J Nature Stud 7 (1): 35-42.

Barcelona JF. 2002. Philippine pteridophyte collections as a resource for conservation planning. Proceedings of the "International Symposium on the Fern Flora Worldwide: Threats and Responses" sponsored by the British Pteridological Society and IUCN-Species Survival Commission." Fern Gaz $16(6,7,8):$ 307-312.

Bharati SK, Manabendra DC, Behari MP. 2013. In Vitro propagation in Pteridophytes: A Review. Intl J Res Ayurveda Pharm 4 (2): 297-303.

Blanca León JHW. 1999. World Economic Plants: A Standard Reference.

Brooks TM, Magsalay P, Dutson G, Allen R. 1995. Forest loss, extinctions and last hope for birds on Cebu. Oriental Bird Club Bull. 21: 24-27.

Brown WH. 1920. Minor Products of Philippine Forests. Bureau of Forestry, Manila.

Buot IE Jr. 1999. Pteridophytes frequently sold at Carbon Market, Cebu: implications to urban horticulture and nature conservation. Philippine Sci 36: 148-153

Burkill HM. 1985. The Useful Plants of West Tropical Africa, Vol 5. Royal Botanic Gardens, Kew, UK

Callaghan TV, Scott R and Whittaker HA. 1981. The yield development and chemical composition of some fast-growing indigenous and naturalized British plant species in relation to management as energy crops. Natural Environment Research Council Contract Report to the Department of the Environment, Philippines.

Chhetri, R. B. 2006. Trend in Ethno domestication of some wild plants in Meghalaya, North East India. Indian J Trad Knowl 53 (3) 342-347. 4.

Collar NJ, Mallari NAD, Tabaranza BR JR. 1999. Threatened birds of the Philippines. The Haribon Foundation/Birdlife International red data book. Bookmark, Makati City, Philippines. 
Conservation International Philippines [C], [DENR-PAWB] Department of Environment and Natural Resources-Protected Areas and Wildlife Bureau, Philippines.

Copeland E.B. 1958-1960. Fern Flora of the Philippines, Vol.1-3. Nat Inst. Sci. Tech. Monogr. 6, Manila.

Delos Angeles M and Buot IE Jr.2018. Altitudinal zonation of ferns along the northeastern slope Mount Makiling, Philippines. Sylvatrop Technical J Philippine Ecosyst Nat Resour 28 (2): 47-68.

Delos Angeles MD and Buot IE Jr. 2012. Orders and families of Philippine Pteridophytes. J Nat Stud 11: 19-33.

Department of Environment and Natural Resources [DENR]. 2017. Updated National List of Threatened Philippine Plants and their Categories [Administrative Order No. 2017-11]

Dhiman AK.1998. Ethnomedicinal uses of some pteridophytic species in India. Indian Fern J 15 (1-2): 61-64.

Esperanza JN. 1993. Taxonomic Study of Vascular Plants on the Northeastern Slope of Mt. Banahaw, Luzon, Philippines. [Hon. Thesis]. College, University of the Philippines Los Baños, Laguna, Philippines.

Fernando ES, Suh MN, LEE J, and Lee DK. 2008. Forest formation of the Philippines. ASEAN-Korea Environmental Cooperation Unit (AKECU). GeoBook Publishing Co.www.geobook.co.kr.

Fernando ES. 2007. Checklist of Species in FBS 21 (Taxonomy of Fores Plants), 12th ed. University of the Philippines Los Baños, Laguna, Philippines.

Giriraj A, Murthy M, and Ramesh B. 2008. Vegetation composition, structure and patterns of diversity: A case study from the tropical wet evergreen forests of the Western Ghats, India. Edin J Bot 65 (3): 1-22.

Haribon [Haribon Foundation for the Conservation of Nature]. 2006 Priority Sites for Conservation in the Philippines: Key Biodiversity Areas. Conservation International Philippines, Quezon City, Philippines.

Herrick J W. 1977. Iroquois Medical Botany. [Dissertation]. State University of New York, Albany, NY.

Huxley A.1992. The New RHS Dictionary of Gardening. Macmillan Press, New York.

International Union for Conservation of Nature [IUCN]. 2017. IUCN updates 'red list' of endangered species. Retrieved from https://www.iucn.nl/en/solutions/red-list-of-threatened-species. IUCN 2011. IUCN Red List of Threatened Species. Version 2011.2.

Kirtikar KR, and Basu BD. 1999. Indian Medicinal Plants, Vol 4, National Book Distributions, Dehradun.

Langhammer PF, Bakarr MI, Bennun LA, Brooks TM, Clay RP, Darwall W, De Silva N, Edgar GJ, Eken G, Fishpool LDC, De Fonseca GAB Foster MN, Knox DH, Matiku P, Radford EA, Rodrigues ASL, Salaman P, Sechrest W, Tordoff AW. 2007. Identification and Gap Analysis of Key Biodiversity Areas: Targets for Comprehensive Protected Area Systems. IUCN Best Practice Protected Area Guidelines Series No. 15. IUCN, Gland, Switzerland.
Legendre P, Borcard D, Peres-Neto PR. 2008. Analyzing or explaining beta diversity comment. Ecology 89 (11): 3238-3244.

Lillo EP, Malaki ABB, Alcazar SMT, Nuevo RU, and Rosales R. 2019. Native Trees on Mt. Lantoy Key BiodiversityAreas (KBA), Argao, Cebu, Philippines. Philippine J Sci 148 (2): 359-371.

Macdonald GM. 2003. Biogeography: Space, Time, and Life. John Wiley \& Sons, Inc., New York.

Magsalay P, Brooks T, Dutson G, Timmins R. 1995. Extinction and conservation on Cebu. Nature 373: 294.

Mallari NAD, Tabaranza BR Jr, Crosby MJ. 2001. Key Conservation Sites in the Philippines: A Haribon Foundation and BirdLife International Directory of Important Bird Areas. In: Lepiten-Tabao M, Gee GA (eds). Bookmark, Inc., Makati City, Philippines.

Mcintosh RI. 1967. An index of diversity and the relation of certain concepts to diversity. Ecology 48: 392-404.

Mcnaughton SJ. 1977. Diversity and stability of ecological communities: A comment on the role of empiricism in ecology. Amer Nat 111: 515525.

Myers NA, Mittermeier RA, Mittermeier CG, Fonseca DA, Gab KJ .2000. Biodiversity hotspots for conservation priorities. Nature 403: 853858.

Odland A, Birks HJB, \& Line JM. 1995. Ecological optima and tolerances of Thelypteris limbosperma, Athyrium distentifolium, and Matteuccia strutbiopteris along environmental gradients in western Norway. Vegetatio 120: 115129

Paguntalan LMJ, Jakosalem PG. 2008. Significant records of birds in forests on Cebu island, central Philippines. Forktail 24: 48-56.

Pappoe AN, Armah FA, Quaye EC, Kwakye PK, Buxton GN. 2010. Composition and stand structure of a tropical moist semi-deciduous forest in Ghana. Intl Res J Plant Sci 1: 95-106.

Rabor DS. 1959. The impact of deforestation on birds of Cebu, with new records for that island. Auk 76: 37-43.

Rivers MC, Bachman SP, Meagher TR, Lughadha EN, and Brummitt NA .2010. Subpopulations, locations and fragmentation: applying IUCN red list criteria to herbarium specimen data. Biodiv Conserv 19: 20712085.

Roux. JP. 2003. Swaziland Ferns and Fern Allies. South African National Biodiversity Institute, Compton Herbarium, Cape Town, SA

Tan HTW. 2011. Singapore Biodiversity. An Encyclopedia of the Natural Environment and Sustainable Development. Didier Millet, Singapore.

Tilman D. 1996. Biodiversity: Population versus ecosystem stability. Ecology 77: 350-363.

Tindall. H. D. 1983. Vegetables in the Tropics. MacMillan, Oxford.

Vogel JC, Rumsey FJ, Schneller JJ, Barrett JA, Gibby M. 1999. Where are the glacial refugia in Europe. Evidence from pteridophytes. Biol J Linn Soc 66: 23-37.

Whitford HN. 1911. The forests of the Philippines. Philippine Bureau of Forestry Bulletin No.10, Manila.

Zhuang, X. 2011. Marsilea crenata. The IUCN Red List of Threatened Species 2011: e.T168620A6523971. DOI: 10.2305/IUCN.UK.20111.RLTS.T168620A6523971. [16 December 2016]. 